\title{
"Las metáforas de la costura". Reseña. Eugenia Prado Bassi. Advertencias de uso para una máquina de coser (segundo borrador). Santiago: Editorial Moda y Pueblo, 2017.
}

El texto de Eugenia Prado nace a partir de su paso por el taller de escritura -curiosamente llamado Moda y pueblo- dirigido por el poeta Diego Ramírez. Curioso es también que una autora con amplio recorrido insista con la experiencia de un taller literario, pero se potencia el gesto al abordar la obra a partir del subtítulo que lleva su última publicación.

"Segundo borrador", habla de un pasado y, por qué no, de un futuro incierto. Cuando se afirma que la escritura dice más allá de lo propiamente dicho, es verdad. En este caso, cuando su autora opta por incluir ese subtitulo lo que hace es revelarnos un proceso y quizá anticiparnos que la escritura no se acaba al publicar un texto. En ese sentido, la letra se concibe como un acto de emergencia, constante y transitorio, nunca definitivo. Porque es móvil, tránsfuga, mutable, así como el lenguaje que es cambiante en la medida en que se usa a través del tiempo. La propuesta de Eugenia Prado es transversal a su obra: la edición de Objetos del silencio (Cuarto Propio, 2007), por ejemplo, dista bastante de la publicada por Ceibo Ediciones en 2015, y eso es una virtud, o una aventura, que no muchos escritores están dispuestos a asumir. Por lo tanto, se puede afirmar que para Prado 
la escritura es también un espacio de rebeldía, de (auto)transgresión a la norma de una lengua fija, estática e institucionalizada.

Ahora bien, la palabra "borrador", a diferencia de la palabra "edición", que apela a un producto ya acabado, sitúa al texto en un lugar específico del campo cultural literario. Borrador, a diferencia de edición, habla de la precariedad, de la autonomía. "Borrador" sitúa a Advertencias de uso para una máquina de coser (2017) en un espacio de cierta marginalidad, desde donde es posible hacer un cuestionamiento a las políticas editoriales de la oficialidad y que también remite a un producto en constante revisión, que se niega a instalarse como un material definitivo e inamovible.

Cada ejemplar es, además, hecho a mano, tal y como lo haría con una prenda un sujeto con su máquina de coser, y eso, sabemos en el arte, incrementa el valor cultural de dicha prenda (no así en el mercado, que es uno de los ejes temáticos que hilvanan la propuesta crítica de esta obra).

En un pasaje del texto, uno de sus personajes comenta: "Unidas por hilos o separadas por filudas tijeras, espejos, botones, veinticinco operarias trabajan en el enorme galpón" (11), y son un grupo de mujeres, precarizadas claro está, las que asumen el papel de (re)productoras de un original al servicio y demanda del mercado. Si bien aplica, en este caso, a la industria de la vestimenta o de la moda, bien podríamos extrapolarlo, y por qué no, a la industria (re)productora de los hijos al servicio de la perversa macroeconomía social. De hecho, una de las protagonistas nombra esto como "los deberes de la biología" (55), pensando en la obligación social de la maternidad, y, ya más conscientes de su lugar en el mercado, comenta que "Nuestros cuerpos configuran una fuerza productiva poderosa" (55). Lo anterior lleva a pensar de inmediato en la posibilidad de interrumpir dicho proceso industrial, o en el aborto y las consecuencias para las madres/trabajadoras: la cárcel o el despido. En este punto es posible llegar a concluir que para Prado el control de la fuerza laboral es también metáfora del control del cuerpo: en ambos casos el cuerpo de la mujer es productor de capital y 
necesita ser controlado para asegurar el flujo y la estabilidad del mercado. Más que una huelga laboral, una huelga de vientres sería devastadora para la continuidad del sistema, en el sentido de que los intereses del capital están estrechamente ligados a las políticas de reproducción que aseguran un stock constante de sujetos productores/consumidores. De este modo, no es descabellado plantear que el ingreso de la mujer a la fuerza de trabajo es apenas una emancipación aparente que responde más bien a intereses bioeconómicos en la obra de Prado.

Este mercado perverso, del que todos formamos parte, del que todos somos clientes, explota y precariza la vida de las sujetos que se sitúan, o han sido situadas, en la base del engranaje productivo. Mientras nosotros disfrutamos de los descuentos, de las ofertas y de las posibilidades de tres o seis cuotas sin interés, a estas sujetos, las veinticinco operarias, “[...] se las ve muy apuradas terminando las prendas antes de que las acaudaladas clientas lleguen a buscarlas" (11). Las clientas, por supuesto, no son las clientas, y la seda es mucho más que la seda. La metáfora que su autora propone implica reconocer una industria mucho más amplia y avasalladora que el pequeño taller. Ese taller es también representación de la llamada "máquina". Máquina como móvil a la cual todos estamos obligados a entrar; desde pequeños nos preparan para asimilarnos a ella: el jardín infantil, el colegio, el instituto profesional, la universidad, no son otra cosa que pequeñas máquinas de coser operadas por otros sujetos precarizados, aunque mucho mejor posicionados, al servicio de la gran industria.

Cómo no reconocerse cuando la narradora comenta que las trabajadoras "Se quejan del exceso de trabajo y, otra vez, al llegar a casa, se quejan de lo mismo, cuando los demás no colaboran. Se quejan de los turnos extendidos. Se quejan del cansancio y más allá del cansancio. Se quejan de la máquina que nunca se detiene" (15). De este modo, las trabajadoras/engranajes evidencian el ciclo al que se someten una vez egresadas de la institucionalidad formadora, que no cumple otro rol que forjar componentes o piezas fundamentales que mueven la maquinaria a la que se incorporan: "Las mujeres teníamos que practicar hasta 
aprender a hacernos la ropa para continuar con nuestras labores femeninas. Al final, salíamos de cuarto medio con vestidos, faldas, blusas y hasta ropa interior cosida por nosotras mismas" (26).

En un momento de lucidez, porque la narradora no forma parte, o mejor dicho, mantiene cierta distancia, se pregunta: “¿Y si uniéramos los textos como cuerdas y desbaratáramos los cierres para escapar de las celdas?” (20). Y esto porque los textos son también cuerpos y los textos son industrializables y ofrecen cierta posibilidad de escape utópico: trabajar los textos, trabajar los cuerpos, es posiblemente una de las maneras de fomentar la conciencia crítica.

"De la casa al taller, del taller a la casa se nos pasa la vida" (41), dice la protagonista y el mercado se nos ofrece como una posibilidad, una válvula de escape. Pero al pensarlo un poco mejor notamos que ese mercado del consumo es parte del mismo esquema productivo en el que estamos inmersos y no podemos, o no queremos, salir de él. Se nos aclara la perversa paradoja: el mercado para el cual trabajamos es productor de más mercado, somos nosotros simplemente los que alternamos los roles: de productores en nuestro tiempo pago, a consumidores en nuestro tiempo libre. 